\title{
Między- i metazmysły - percepcja w dobie sztuki multimedialnej
}

DOI: $10.14746 /$ rfn.2018.19.3

Przyjmuje się, że percepcja subiektywnie interpretuje świat zewnętrzny, konstruując spostrzeżenia poprzez zmysły, czyli m.in. widzenie, słyszenie, dotykanie, odczuwanie temperatury. Ale rzeczywistość nie jawi się nam w postaci poszczególnych danych zmysłowych, lecz całościowo. Zmysły nie działają osobno, $\mathrm{z}$ natury są powiązane, ponieważ ich wzajemne oddziaływanie niewspółmiernie zwiększa siłę przekazu; zgodnie $\mathrm{z}$ arystotelesowskim założeniem - całość to więcej niż suma części.

Jeszcze w pierwszej połowie XX wieku filozof Maurice Merleau-Ponty fenomenologicznie opisuje postrzeganie jako ,jeden jedyny nieumiejscowiony proces poznawczy, duszę nierozkładalną na części”' Poza tym stwierdza, że ukierunkowane, świadome „doświadczanie odseparowanych od siebie «zmysłów», jest nietrwałe i obce naturalnej percepcji”. Z kolei ciało jest dla Merleau-Ponty’ego

systemem utkanym w całości z odwzorowań i przekształceń międzyzmysłowych. Zmysły przekładają się na siebie nawzajem, nie potrzebując do tego tłumacza, rozumieją się nawzajem, bez pośrednictwa idei ${ }^{2}$.

1 M. Merleau-Ponty, Fenomenologia percepcji, przeł. M. Kowalska, J. Migasiński, Warszawa 2001 (pierwsze wydanie: Éditions Gallimard, Paris 1945), s. 233.

2 Ibidem.
Swe poglądy francuski egzystencjalista opierał na przekonaniu, że percepcja zakorzeniona jest w przedrefleksyjnym jeszcze, wspólnym dla wszystkich ludzi świecie doznań.

Również Arnold Berleant poddał krytyce rozróżnienie na to, co sensualne (sensuous) - intelektualny ogląd z dystansu - i to, co zmysłowe (sensual), czyli doznania cielesne. Ciało „nasiąka” bowiem doświadczeniami międzyzmysłowymi i tak zapamiętuje świat, bo są silniejsze niż czyste obrazy, dźwięki albo czyste wrażenia dotykowe ${ }^{3}$. Każda modalność niesie inną informację o otoczeniu, ale zmysły nieustannie komunikują się między sobą, dzięki czemu powstaje pełne, całościowe doznanie.

Jednym z nowatorskich sposobów badania związku między percepcją a odczuwanymi przez człowieka wrażeniami stało się badanie reakcji mózgu na sztukę, w tym muzykę. Próbę sformułowania uniwersalnych, podstawowych praw dotyczących doświadczania estetycznego podjął neurobiolog Vilayanur Ramachandran ${ }^{4}$. Ustalone przez niego reguły nie uwzględniły

3 A. Berleant, The Sensuous and the Sensual in Aesthetics, „Journal of Aesthetics and Art Criticism” 1964 t. 23 nr 2, s. 185-192.

4 Wśród nich wyróżnia m.in.: uwypuklenie elementów i ich różnic; abstrahowanie istotnych cech obiektów; grupowanie percepcyjne i oddzielenie tła; metaforyzowanie jako podstawowy mechanizm poznawczy. Zob. V.S. Ramachandran, The Artful Brain, http:// www.bbc.co.uk/radio4/reith2003/lecture3.shtml (3.03.2017). 
jednak wszystkich aspektów ważnych przy odbiorze dzieła, np. jego oryginalności, dlatego w ostatnim czasie podjęto próby rozszerzenia neuroestetycznego paradygmatu. Dopiero badania naukowe ostatnich dekad pozwalają lepiej rozumieć, jak informacje z poszczególnych zmysłów są integrowane w użyteczne, metazmysłowe reprezentacje zewnętrznej rzeczywistości. Poszukiwania „umysłu estetycznego” oraz badania neuronalnych uwarunkowań emocji estetycznych prowadzi m.in. Semir Zeki. Przeprowadzone przez niego eksperymenty wskazują, że zdolność odczuwania piękna nie jest bezpośrednio zależna od rodzaju zmysłu oraz że istnieją w mózgu obszary wspólne dla wzrokowej i słuchowej percepcji estetycznej ${ }^{5}$. Współczesne, interdyscyplinarne platformy badawcze potwierdzają zatem wiele tez filozofów.

Pod koniec XX wieku zebrano liczne argumenty na potwierdzenie hipotez „ucieleśnienia poznania” oraz „poznania rozproszonego”, wedle których nie tylko mózg i system nerwowy, ale też inne układy ludzkiego ciała biorą udział w procesach poznawczych ${ }^{6}$. $\mathrm{W}$ najnowszych tendencjach badawczych utożsamia się więc poznanie $\mathrm{z}$ działaniem, a myślenie $\mathrm{z}$ wnioskowaniem opartym na schematach motorycznych i metaforycznych ${ }^{7}$. Potwierdzono też, że muzyka jest związana z pamięcią i emocjami poprzez ruch. W czasie słuchania muzyki - nie tylko podczas koncertu zdarzenia akustyczne analizowane są w kontekście wyobrażonych, domyślnych bodźców wizualnych, a interpretacja gestów konfrontowana jest $\mathrm{z}$ doświadczeniem. Słuchacz wyobraża sobie dźwięk i jego źródło, śledząc jego obwiednię i barwę najczęściej poprzez metaforę kształtu' ${ }^{8}$. Nawet jeżeli wykonawcy są niewidoczni, odbiorca domyśla się, jakich ruchów i gestów używa się $\mathrm{w}$ procesie wydobywania danego dźwięku. Innymi słowy, odbiorca automatycznie wciela się w stan osoby mówiącej, wiedząc, jak musiałby się czuć, gdyby używał tych samych gestów (w kontakcie z muzyką wykonaną na żywo podczas koncertu proces ten zostaje sprzężony $\mathrm{z}$ bodźcami wzrokowymi). To

5 T. Ishizu, S. Zeki, W stronę neurobiologicznej teorii piękna, przeł. S. Bodzak, B. Tatar, „Via Mentis” 2012 t. 1, s. 113.

6 G. Bateson i in., The Embodied Mind: Cognitive Science and Human Experience, Massachusetts 1991.

G. Lakoff, M. Johnson, Philosophy in the Flesh. The Embodied Mind and Its Challenge to Western Thought, New York 1999.

8 A. Cox, The Mimetic Hypothesis and Embodied Musical Meaning, ,Musicae Scientiae” 2001 t. 5 nr 2, s. 195-212. swoiste mimesis jest integralną częścią muzycznego doświadczania9 i uczenia się.

W latach 90. nowe światło na psychoakustyczne tajniki percepcji rzuciła szeroko komentowana teoria sceny słuchowej (ang. auditory scene) Alberta S. Bregmana ${ }^{10}$. Teoria ta wpisuje się w nurt muzykologii zorientowanej kognitywnie, która w opisach trudnych do konceptualizacji zjawisk stosuje m.in. reguły zapożyczone z psychologii poznawczej i psychologii Gestalt (psychologii postaci ${ }^{11}$ ). Bregmanowska koncepcja zakłada wyodrębnianie i kształtowanie się w czasie słuchania tzw. strumieni słuchowych oraz audytywnych postaci (niem. Gestalten). Te mentalne reprezentacje muzyczne składają się z dynamicznych obrazów, które przez chwilę są podtrzymywane, następnie zmieniają się i w końcu zanikają. Umysł nieustannie odwołuje się przy tym do doświadczeń zachowanych w postaci tzw. spektrogramów neuronalnych.

Przywołane koncepcje naukowe pozwalają wnioskować, że bodźce słuchowe na wyższych piętrach słyszenia (związanych $\mathrm{z}$ rozumieniem i pamięcią) mają charakter między- i metazmysłowy. Muzyczne poznanie i interpretacja nie są więc kwestią czystego doświadczenia słuchowego; to złożony proces angażujący długi łańcuch wyspecjalizowanych mechanizmów. Podobne wnioski wysnuwa muzykolog i filozof Marcin Trzęsiok, opisując to zjawisko na przykładzie odczuwania czasu muzycznego:

Zaangażowani $\mathrm{w}$ proces rozwijania się dzieła w czasie, włączamy kolejne dźwięki w nurt opowieści muzycznej i oczekujemy dalszego rozwoju wydarzeń. I choć nie udaje się ogarnąć całości, usiłowanie to pochłania stopniowo coraz więcej uwagi. Taki sposób słuchania jest, rzecz jasna, zasadny: wewnętrzne powiązania są istotą formy, a forma winna stać się przedmiotem wyrafinowanej percepcji estetycznej. Osobliwie, okazuje się, że nasze starania zmierzają ostatecznie do zniesienia czasu. [...] Zapamiętane związki narracyjne pozwalają umysłowi wędrować swobodnie w przeszłość dzieła. Świeżość bezpośredniej percepcji zostaje przesłonięta

9 R.I. Godøy, Motor-Mimetic Music Cognition, „Leonardo” 2003 t. $36 \mathrm{nr} 4$, s. 317-319.

10 A.S. Bregman, Auditory Scene Analysis, Cambridge 1990.

${ }^{11}$ Nurt Gestalt pojawił w pierwszej połowie XX wieku na gruncie psychologii niemieckiej. Ta nowatorska teoria percepcji przewartościowała wiedzę dotyczącą relacji między całością a składającymi się nań częściami, tego, jak całość i jej części są postrzegane przez umysł oraz jak całość jako figura wyłania się z tła. 
przez abstrakcje - trudny do opisania amalgamat wyobrażeń słuchowych, wizualnych i konceptualnych [...]. Dzieło muzyczne traci słyszalną konkretność. Na jego miejsce wchodzi projekcja wyimaginowanego przedmiotu, który jest interpretowany w terminach całkowicie pozamuzycznych ${ }^{12}$.

Narracyjne kategorie słuchowej interpretacji skłaniają m.in. do szukania podobieństw między muzyką a językiem. Aniruddh Patel postawił niedawno tezę tzw. schematu dzielonych zasobów (ang. resource sharing framework), która zakłada sprzężone przetwarzanie informacji muzycznej i językowej ${ }^{13}$. Z kolei Piotr Podlipniak uważa, że „muzyczne reprezentacje poznawcze odzwierciedlają postacie gestykulacyjne związane z poziomem przedkonceptualnym"14. Istnieją bowiem dowody, że sfery ruchu i dźwięku były ze sobą zawsze ściśle związane, gdyż muzyka, podobnie jak gest, to prawdopodobnie przedjęzykowa zdolność człowieka ${ }^{15}$, a co za tym idzie, uniwersalna forma ekspresji.

Koncepcja ucieleśnionego poznania bierze pod uwagę wpływ kultury i środowiska, w jakim powstają i funkcjonują ciało i umysł, wszakże człowiek stale przyswaja i wykształca nowe schematy poznawcze. $\mathrm{Z}$ tego wynika, że sytuacje i doświadczenia będące podstawą procesu uczenia się prowadzą do zmian zdolności i sprawności percepcji, kształtują także gust i wrażliwość. Ufundowane naturalną ewolucją możliwości słuchu na przestrzeni ostatnich tysiącleci pozostawały takie same, ale odbiór muzyki - jako wyspecjalizowana umiejętność i międzyzmysłowy proces interpretacyjny - już w obrębie ostatnich wieków zmienił się znacząco (muzyka Chopina za jego życia nazywana była „rozdzierającą kakofonią”" ${ }^{16}$ ). Sposób słuchania muzyki zmienia się zatem wraz z nią samą i jest mocno uwarunkowany kulturowo. W przypadku muzyki nowej, atonalnej, zwłaszcza elektroakustycznej, często brakuje poznawczych modeli i wzorców, stąd większe trudności w odbiorze, zwłaszcza u osób

\footnotetext{
${ }_{12}$ M. Trzęsiok, Muzyka doświadczenia, „Res Facta Nova” 2007 t. 9, s. 169-183.

13 A.D. Patel, Language, Music, and the Brain: A Resource-Sharing Framework, [w:] Language and Music as Cognitive Systems, red. P. Rebuschat i in., Oxford 2012, s. 204-223.

${ }_{14}$ P. Podlipniak, Uniwersalia muzyczne, Poznań 2007, s. 54.

${ }_{15}$ Ibidem, s. 77, 106.

${ }^{16}$ N. Slonimsky, Lexicon of Musical Invective, New York 1953, s. 84.
}

niewykwalifikowanych, mogących oprzeć się jedynie na najprostszych, uniwersalnych mechanizmach.

Intermodalne zdolności percepcyjne człowieka są wrodzone, choć zmieniają się i kształtują wraz z wiekiem. Zmiany te podążają jednocześnie w stronę integracji oraz separacji zmysłów, tzn. człowiek uczy się zarówno scalać wielozmysłową całość, jak i skupiać się na pojedynczej modalności ${ }^{17}$. W ostatnim czasie, zwłaszcza wśród pokolenia tzw. cyfrowych tubylców ${ }^{18}$, to drugie wydaje się coraz trudniejsze. Tymczasem zachodnioeuropejska kultura u swego zarania opierała się na paradygmacie słyszalności. Wolfgang Welsch przypomina, że prymat widzenia rozpoczął się dopiero w V wieku p.n.e., a spełnił u Platona ${ }^{19}$. W myśl łacińskiej sentencji verba volant, scripta manent („słowa ulatują, pismo pozostaje"), wolno, acz konsekwentnie toczyło się rozprzestrzenianie pisma i kształtowanie kultury słowa pisanego, „widzialnego”. Wynalazek druku znacznie przyspieszył tę ewolucję: „głos ludzki cichł i milkł w miarę, jak gutenbergowski druk wypełniał świat. Ludzie przyjęli rolę konsumentów słowa, czytając je po cichu i w sposób całkowicie bierny"20 pisał pionier medioznawstwa Marshall McLuhan. Również tacy badacze kultury, jak Walter Jackson Ong czy Derrick de Kerckhove, zwracają uwagę na to, że umiejętności słuchowe wraz z ekspansją pisma, druku, rozwojem technologicznym i szeroko pojętą dominacja wizualności ulegają zubożeniu.

W wieku XX komunikację i kulturę zdominowała audiowizualność. Rozwój filmu, telewizji, później internetu i innych mediów sprawił, że dynamiczne dźwięki i obrazy zaczęły coraz częściej pojawiać się w codziennym życiu każdego człowieka, stopniowo przekształcając jego świadomość, sposób myślenia i wyobraźnię. Kultura narzuciła audiowizualne doświadczanie świata, zmuszając do wykształcenia się nowego rodzaju postrzegania, który Maryla Hopfinger

${ }_{17}$ D.J. Lewkowicz, The Development of Temporal and Spatial Intermodal Perception, [w:] Cognitive Contributions to the Perception of Spatial and Temporal Events, red. G. Aschersleben i in., Amsterdam 1999, s. 397-407.

${ }_{18}$ M. Prensky, Digital Natives, Digital Immigrants, „On the Horizon" 2001 t. 9 nr 5, s. 1-6.

${ }_{19}$ W. Welsch, Na drodze do kultury styszenia?, przeł. K. Wilkoszewska, [w:] Przemoc ikoniczna czy „Nowa widzialność"?, red. E. Wilk, Katowice 2001, s. 59.

${ }^{20}$ M. McLuhan, Galaktyka Gutenberga, [w:] idem, Wybór pism, przeł. K. Jakubowicz, Warszawa 1975, s. 262. 
nazwała syndromem a u di owizualnym ${ }^{21}$. Słuch ma zresztą wiele wspólnego ze wzrokiem - widzenie i słyszenie świetnie uzupełniają się nawzajem, tworząc integralny system zmysłów dystansu, czyli działających na odległość. Wzrok przoduje w analizie obiektów, ale to słuch nakierowuje uwagę na szukane przedmioty; uwydatnia też czasoprzestrzenność dźwięków. Warto jednak zaznaczyć, że o ile odbiór muzyki bez towarzyszącego jej obrazu jest czynnością komfortową z psychologicznego punktu widzenia, o tyle ruchomy obraz bez dźwięku jest mniej akceptowalny. Naturalne jest tworzenie w wyobraźni obrazów odpowiadających słuchanej muzyce, zwłaszcza programowej, ale o wiele trudniejsze wydaje się mentalne „dokomponowanie” muzyki do obrazu.

Problem percepcyjnego integrowania warstw audialnej i wizualnej oraz jednakowej wagi obrazu i dźwięku porusza francuski kompozytor i filmoznawca Michel Chion. Odnosząc się do kina, nie odmawia warstwie audio i wideo niezależności i odrębności formalnej, jednocześnie podkreśla ich nieuniknione uzupełniania się i przenikanie $\mathrm{w}$ procesie postrzegania. Refleksja Chiona dowartościowuje przy tym rolę dźwięku w sposób o wiele mocniejszy, niż czyniono to w dotychczasowych, wzrokocentrycznych teoriach tego rodzaju. Co więcej, proponuje w swych pracach nową, własną terminologię oraz poparte licznymi przykładami metodologiczne modele audiowizualnej analizy ${ }^{22}$.

U podstaw dalszych zmian postrzegania legła błyskawiczna ekspansja interaktywnej elektroniki i multimediów. Język przestał być matrycą organizującą budowę obrazów świata; stały się nią ruchome, wieloznaczne i wielopoziomowe „obrazoświaty”: emotikony, memy i gify. Pokolenia ukształtowane przez internet, komputer, smartfony i inne dotykowe gadżety cechuje specyficzne postrzeganie rzeczywistości przez pryzmat tychże mediów ${ }^{23}$. Kultura, wkraczając w fazę

${ }^{21}$ M. Hopfinger, Doświadczenia audiowizualne: o mediach $w$ kulturze wspótczesnej, Warszawa 2003, s. 32-33.

22 Zob. M. Chion, Audio-Vision: Sound on Screen, przeł. C. Gorbman, New York 1994; wydanie polskie: Audio-wizja. Dźwięk i obraz w kinie, przeł. K. Szydłowski, Warszawa-Kraków 2012.

${ }^{23}$ Wokół pokoleniowej „zmiany warty”, będącej bezpośrednim następstwem cyfrowej rewolucji, krążą niezwykle popularne w ostatnim czasie tezy Harry’ego Lehmanna, wedle którego artyści całkowicie oswojeni i „zadomowieni” w środowisku nowych mediów przesuwają twórcze wysiłki z rozwijania organizacji materiału dźwiękowego mediów cyfrowych, wzbogaciła więc percepcję o nowy metazmysł, który, za Antonim Porczakiem, można by nazwać „w r a żli iw ós cią multimedialną"24.

Tomasz Misiak uważa, że „efekty techniki nieuchronnie zmieniają proporcje naszych zmysłów [...], dehierarchizują, reorganizują naszą percepcję"25. Multimedia wyrywają człowieka z czasu linearnego, zmieniają odczucie czasoprzestrzeni. Z kolei Mirosław Filiciak pisze:

Rozróżnienie na to co już się stało, dzieje się obecnie i stanie się za chwilę jest w rządzącym się pofragmentaryzowaną logiką bazy danych współczesnym świecie problematyczne czas jest „bezczasowy”, ani linearny, ani cykliczny. Rozbity na wiele równoległych strumieni, pomiędzy którymi możemy się przełączać ${ }^{26}$.

Ewa Trębacz, kompozytorka, także uważa, że charakter naszej percepcji ewoluuje $\mathrm{w}$ stronę symultaniczności doświadczeń przy jednoczesnym rozproszeniu uwagi:

Ten nowy w swej powszechności, symultaniczny, wielowątkowy, intermedialny i wielowymiarowy, a jednocześnie „krótkodystansowy” sposób postrzegania świata ma i będzie miał zasadnicze konsekwencje dla dalszego rozwoju sztuki ${ }^{27}$.

Sztuka rozszerza poznanie, gdyż zasadniczym narzędziem jej rozumienia jest abstrahowanie, zdolność uogólniania, wychodzenia poza pojedyncze przypadki. Ale od kiedy symultaniczność i wielowątkowość stały się normą, dłuższe skupienie się na pojedynczym kanale percepcji przedstawia coraz większą trudność. Sama mowa czy dźwięki nie wystarczają. Coraz rzadziej słucha się radia, skupiając się jedynie na tej właśnie

na treść - jej odniesienia do rzeczywistości, problematyki społeczno-politycznej. Zob. H. Lehmann, Rewolucja cyfrowa w muzyce. Filozofia muzyki, przeł. M. Pasiecznik, Warszawa 2016.

${ }^{24}$ A. Porczak, Wrażliwość multimedialna: sztuka globalna, Kraków 1996.

${ }_{25}$ T. Misiak, Od przestrzeni akustycznej do akustycznej cyberprzestrzeni. Styszenie $w$ refleksji filozoficznej a muzyka elektroniczna, Poznań 2007, http://kaleka.net/files/od_przestrzeni_akustycznej_do_ akustycznej_cyberprzestrzeni.\%20 doc (3.03.2017).

${ }^{26}$ M. Filiciak, Media i czas - czyli o tym, że nie tylko przyszłość nie jest tym, czym była, http://www.csw.art.pl/index.php?action=aktualnosci\&s2=1\&id=319\&lang= (3.03.2017).

${ }^{27}$ E. Trębacz, Petna imersja: rzeczywistość czy utopia? Technologie przestrzenne z punktu widzenia artysty, „Glissando” 2010 t. 16, s. 44. 
czynności. Można ćwiczyć umiejętność koncentracji na wybranym rodzaju bodźców, np. na muzyce, ale trudno słuchać osobno - umysł chce widzieć, słuchać i czuć jednocześnie. Multimedia i metazmysłowe doświadczenia kulturowe zostały zatem uprzywilejowane przez mechanizmy odbiorcze. Dlatego muzyka nadal jest uważana za najbardziej abstrakcyjną i nieuchwytną ze sztuk. Słuchanie jest wymagające dla umysłu, bo skłania go do samodzielnego rozbudzenia wyobraźni (tak jak czytanie książek przez niektórych jest uważane za bardziej rozwijające niż oglądanie filmów, bo nie daje gotowych reprezentacji wizualnych). Percepcja samej muzyki, na przykład z zamkniętymi oczami, zostawia obszar niedookreśleń, które na wyższych piętrach postrzegania mogą być twórczo uzupełniane. Taka zmysłowa konwergencja - czyli bezpośrednia przechodniość danych zmysłowych jak w synestezji jest możliwa, bo dźwięk istnieje wówczas wyłącznie w postaci uniwersalnego kodu, czyli elektrochemicznych pobudzeń neuronalnych.

Może wydawać się to paradoksalne, ale podczas gdy neuronauki usilnie zajmują się percepcją dźwię$\mathrm{ku}$, muzyki czystej jest coraz mniej. W zasadzie tylko poważna twórczość okołoakademicka i jazz bywają autentyczną muzyką absolutną, czyli czystą grą dźwięków. Popkulturę, w całej jej rozciągłości, zdominowały tzw. supersystemy rozrywkowe oparte na narracjach transmedialnych ${ }^{28}$, obecnych nie tylko w grach komputerowych i biznesie filmowym (np. Wiedźmin - pierwotnie opowiadania i powieści Andrzeja Sapkowskiego, następnie film fabularny i serial telewizyjny, wreszcie komiks i gra komputerowa), ale i we współczesnej muzyce (np. Imaginaerum - koncepcyjny album muzyczny grupy Nightwish i jednocześnie fińsko-kanadyjski film muzyczny w reżyserii Stobe Harju). Nowe narzędzia i możliwości, ale też nowy sposób postrzegania przez człowieka, zwróciły większą uwagę artystów na coś, co zawsze pozostawało poza zasięgiem pełnej kontroli, co było marginaliami wykonania. Artyści dzięki nowym mediom zyskali możliwość łamania granic modalności, co z kolei wpisuje się w tzw. renesans zmysłowości.

28 Opowieść transmedialna to „wielowątkowa i zróżnicowana historia, która odsłaniana jest na różnych platformach medialnych, przy czym każde medium ma swój oddzielny wkład w tworzenie i rozwijanie fikcyjnego świata”; H. Jenkins, Kultura konwergencji. Zderzenie starych $i$ nowych mediów, przeł. M. Bernatowicz, M. Filiciak, Warszawa 2008, s. 260.
W tak ustawionym kontekście sztuka performatywna, audiowizualna czy multimedialna jest o wiele bardziej dosłowna, łatwiejsza w odbiorze, bo angażując jednocześnie wiele zmysłów, pozostawia mniej miejsca na kreatywne doświadczanie. Mniejsze jest pole odbiorczej interpretacji, ale komunikat jest silniejszy, staje się neuroestetycznym „superbodźcem”29 czy nawet somatyczną używką. Warto postawić zatem pytanie: gdzie leży granica między zmysłową pieszczotą a gwałtem?

Adekwatną do tego problemu sytuacją estetyczną $\mathrm{w}$ świecie nowych mediów jest immersja, postrzeżeniowy fenomen związany $\mathrm{z}$ wirtualną rzeczywistością $^{30}$.Zanurzenie interaktora w sztucznie generowanej cyberprzestrzeni ${ }^{31}$ pochłania jego zdolności percepcyjne, znosząc granice między mediami a podmiotem. W muzyce idea immersji pojawia się od początku fonografii aż po vocaloidy i wirtualnych wykonawców (np. Gorillaz - wirtualny zespół muzyczny wydający płyty, filmy i książki). Rozwój technologii nagraniowych i nagłośnienia zmierzał w kierunku uzyskania akustycznego symulakrum, czyli Baudrillardowskiej hiperrzeczywistości, w której nie dałoby się odróżnić odtworzenia od wykonania. Wszakże w wirtualnym środowisku chodzi nie tylko o iluzję, lecz o jej przekroczenie, o poczucie „bycia” wewnątrz. Przełamując zdystansowany ogląd, zmysły mają być niejako przedłużone bądź przeniesione. Idąc o krok dalej, można by stwierdzić, że immersja na odległość jest symulacją obecności, swoista „zmysłową teleportacją" ${ }^{32}$.

Ale wirtualność to nie tylko odtwarzanie. W sztuce immersyjnej deformującej rzeczywistość może dochodzić do zaburzeń relacji doznań zmysłowych i jej celowej reorganizacji czy dezintegracji. W tej wielozmysłowej niesynchroniczności świadomy odbiorcainteraktor silniej niż przekaz postrzeże sam sposób

${ }^{29}$ V. Ramachandran, W. Hirstein, Nauka wobec zagadnienia sztuki. Neurologiczna teoria doświadczenia estetycznego, przeł. M.B. Florek, P. Przybysz, [w:] Studia z kognitywistyki i filozofii umysłu, t. 2, red. W. Dziarnowska, A. Klawiter, Poznań 2006, s. 327-363.

30 Pierwsze tego rodzaju technologie - pod nazwą CAVE (Cave automatic virtual environment) - zrealizowano w roku $1992 \mathrm{w}$ Chicago Electronic Visualization Laboratory przy Uniwersytecie w Illinois. Za pierwsze użycie immersyjnej rzeczywistości wirtualnej w sztuce uznaje się projekt Charlotte Davies Osmose (1995).

31 M. Pisarski, Cyberprzestrzeń - zjawisko immersji, „Techsty”, http://www.techsty.art.pl/hipertekst/cyberprzestrzen/immersja.htm (3.03.2017).

32 Zob. A. Szatanik, Teleimersja, http://www.wbc.poznan.pl/Content/1129/teleimersja.pdf (3.03.2017). 
postrzegania. Sztuka staje się wówczas nie tyle wehikułem znaczeń, co znaczącym wehikułem, zgodnie ze słynną tezą McLuhana: medium is the message $e^{33}$.

Immersyjne dzieło zyskuje zwykle formę interaktywnego performansu lub wielkogabarytowej instalacji, w której głównym czynnikiem staje się przestrzeń medialnych interakcji, jak chociażby w słynnym Pawilonie Phillipsa zaprojektowanym na Wystawę Międzynarodową w Brukseli w roku 1958 przez architekta Le Corbusiera i kompozytora Iannisa Xenakisa. Istotą takiej sztuki stało się przekraczanie zastanych podziałów i konstytuowanie przekazów w nowej przestrzeni "między" 34 jako sceny wzajemnych relacji. Te nowe środki celowo uderzają $\mathrm{w}$ przyzwyczajenia percepcyjne, a niekiedy wręcz wymuszają nowe mechanizmy i odmienne stany świadomości. Artyści nowych mediów budują zatem na tym, co cielesne i zmysłowe. Ontologiczne pytanie „czym jest dzieło sztuki?” przeformułowano na ,jak się je odczuwa?”. Już Józef Robakowski, pionier polskiej sztuki wideo, przekornie pisał, że:

Posługując się współczesną techniką chcę skompromitować własne nawyki percepcji. [...] Mając świadomość, że wyobraźnia, intuicja oraz stosowane obecnie sposoby znakowania są niedoskonałe, odwołuję się do metod przyjętych w nauce i do rozwoju techniki ${ }^{35}$.

Z kolei Włodzimierz Borowski, twórca performansów i instalacji, przyznaje:

Początkowo syntetyzowałem rodzaj świadomości czystej abstrakcji: na pograniczu muzyki i doświadczenia plastycznego. [...] Obiekt-obraz istnieje, ale w momencie jego percepcji ujawnia on inny wymiar, otwiera przestrzeń, tworzy wyłom, otwór, przez który wchodzimy gdzieś indziej ${ }^{36}$.

Te nowe „meta-wymiary” $i$ „między-przestrzenie” percepcji, o których pisze Borowski, wciąż czekają na naukową eksplorację.

${ }_{33}$ M. McLuhan, Understanding Media: The Extensions of Man, New York 1964, s. 7.

${ }^{34}$ K. Chmielecki, Estetyka intermedialności, Kraków 2008, s. 11. 1977.

${ }^{35} \mathrm{~J}$. Robakowski, Stan świadomości (katalog wystawy), Łódź

${ }^{36}$ J. Bury, Kreowanie pustki - rozmowa z Włodzimierzem Borowskim, „Opcje” 2001 nr 5, s. 44-48.
$* * *$

Sztuka nowych mediów lubi wystawiać zmysły na próbę. Jest grą z percepcją, z jej ograniczeniami i możliwościami. Często chodzi w niej o zmianę perspektywy postrzegania rzeczywistości, wyjście poza klasyczny, kartezjański jeszcze model antropocentrycznej wizji odbioru i definiowania świata. Bo człowiek jest coraz bardziej złakniony poszerzenia pola swojej percepcji, chce więcej doświadczać, więcej czuć, więcej przeżywać. Niektórzy artyści, jak chociażby kompozytor muzyki konceptualnej Johannes Kreidler, posługując się nowymi środkami, chcą zdemaskować wpływ mediów na życie współczesnego człowieka, na jego przebodźcowaną wrażliwość poznawczą i estetyczną.

Intensyfikacja percypowania niejednokrotnie jawi się odbiorcom jako uwolnienie, eskapizm, ale też jako poszukiwanie nowych sposobów poznania. Rodzą się jednak pytania: czy w obliczu nowych mediów i nowych sytuacji estetycznych wykształcą się jeszcze inne umiejętności percepcyjne? Czy neuroestetyka potwierdzi istnienie tych nowych zmysłów? I wreszcie: czy przez transhumanizm i cyborgizacje człowiek postawi kolejny krok na długiej drodze swej „zmysłowej ewolucji”?

\section{BIBLIOGRAFIA}

Bateson Gregory i in., The Embodied Mind: Cognitive Science and Human Experience, MIT Press, Cambridge, Massachusetts 1991.

Berleant Arnold, The Sensuous and the Sensual in Aesthetics, „Journal of Aesthetics and Art Criticism” 1964 t. 23 nr 2, s. $185-192$.

Bregman Albert S., Auditory Scene Analysis, MIT Press, Cambridge, Massachusetts 1990.

Bury Józef, Kreowanie pustki - rozmowa $z$ Włodzimierzem Borowskim, „Opcje” $2001 \mathrm{nr} 5 / 40$, s. 44-48.

Chion Michel, Audio-wizja. Dźwięk i obraz w kinie, przeł. Konstanty Szydłowski, Stowarzyszenie Nowe Horyzonty, Warszawa-Kraków 2012.

Chmielecki Konrad, Estetyka intermedialności, Rabid, Kraków 2008.

Cox Arnie, The Mimetic Hypothesis and Embodied Musical Meaning, „Musicae Scientiae” 2001 t. 5 nr 2, s. 195-212.

Filiciak Mirosław, Media i czas - czyli o tym, że nie tylko przyszłość nie jest tym, czym była, http://www.csw.art.pl/ 
index.php?action=aktualnosci\&s $2=1 \& \mathrm{id}=319 \& \mathrm{lang}=$ (3.03.2017).

Godøy Rolf Inge, Motor-Mimetic Music Cognition, „Leonardo" 2003 t. 36 nr 4, s. 317-319.

Hopfinger Maryla, Doświadczenia audiowizualne: o mediach w kulturze współczesnej, Sic!, Warszawa 2003.

Jenkins Henry, Kultura konwergencji. Zderzenie starych i nowych mediów, przeł. Małgorzata Bernatowicz, Mirosław Filiciak, Wydawnictwa Akademickie i Profesjonalne, Warszawa 2008.

Lakoff George, Mark Johnson, Philosophy in the Flesh. The Embodied Mind and Its Challenge to Western Thought, Basic Books, New York 1999.

Lehmann Harry, Rewolucja cyfrowa w muzyce. Filozofia mu$z y k i$, przeł. Monika Pasiecznik, Fundacja Bęc Zmiana, Warszawa 2016.

Lewkowicz David J., The Development of Temporal and Spatial Intermodal Perception, [w:] Cognitive Contributions to the Perception of Spatial and Temporal Events, red. Gisa Aschersleben i in., Elsevier Science B.V., Amsterdam 1999.

McLuhan Marshall, Galaktyka Gutenberga, [w:] idem, Wybór pism, przeł. Karol Jakubowicz, Wydawnictwa Artystyczne i Filmowe, Warszawa 1975.

Merleau-Ponty Maurice, Fenomenologia percepcji, przeł. Małgorzata Kowalska, Jacek Migasiński, Fundacja Aletheia, Warszawa 2001

Misiak Tomasz, Od przestrzeni akustycznej do akustycznej cyberprzestrzeni. Styszenie $w$ refleksji filozoficznej a muzyka elektroniczna, Poznań 2007, http://kaleka.net/files/ od_przestrzeni_akustycznej_do_akustycznej_cyberprzestrzeni.\%20 doc (3.03.2017).

Patel Aniruddh D., Language, Music, and the Brain: A Resource-Sharing Framework, [w:] Language and Music as Cognitive Systems, red. Patrick Rebuschat i in., Oxford University Press, Oxford 2012.

Pisarski Mariusz, Cyberprzestrzeń - zjawisko immersji, „Techsty", http://www.techsty.art.pl/hipertekst/cyberprzestrzen/ immersja.htm (3.03.2017).

Podlipniak Piotr, Uniwersalia muzyczne, Wydawnictwo Poznańskiego Towarzystwa Przyjaciół Nauk, Poznań 2007.

Porczak Antoni, Wrażliwość multimedialna: sztuka globalna, Bunkier Sztuki, Kraków 1996.

Prensky Marc, Digital Natives, Digital Immigrants, „On the Horizon" 2001 t. 9 nr 5, s. 1-6.

Ramachandran Vilayanur S., The Artful Brain, http://www. bbc.co.uk/radio4/reith2003/lecture3.shtml (3.03.2017).

Ramachandran Vilayanur, Hirstein William, Nauka wobec zagadnienia sztuki. Neurologiczna teoria doświadczenia estetycznego, przeł. Monika Blanka Florek, Piotr Przybysz, [w:] Studia z kognitywistyki i filozofii umystu, t. 2, red. Wioletta Dziarnowska, Andrzej Klawiter, Zysk i S-ka, Poznań 2006.

Robakowski Józef, Stan świadomości (katalog wystawy), BWA, Łódź 1977.

Slonimsky Nicolas, Lexicon of Musical Invective, Coleman-Ross, New York 1953.

Szatanik Anna, Teleimersja, http://www.wbc.poznan.pl/Content/1129/teleimersja.pdf (3.03.2017).

Tomohiro Ishizu, Semir Zeki, W stronę neurobiologicznej teorii piękna, przeł. Sebastian Bodzak, Barbara Tatar, „Via Mentis” 2012 t. 1, s. 113-137.

Trębacz Ewa, Pełna imersja: rzeczywistość czy utopia? Technologie przestrzenne z punktu widzenia artysty, „Glissando” 2010 t. 16, s. 44-48.

Trzęsiok Marcin, Muzyka doświadczenia, „Res Facta Nova” 2007 t. 9, s. 169-183.

Welsch Wolfgang, Na drodze do kultury styszenia?, przeł. Krystyna Wilkoszewska, [w:] Przemoc ikoniczna czy „Nowa widzialnośc'?, red. Eugeniusz Wilk, Uniwersytet Śląski, Katowice 2001, s. 56-74.

\section{SUMMARY}

\section{Andrzej Mądro}

\section{Inter- and metasenses - perception in the age of multimedial art}

The mechanism of perceiving the world by mankind is still an unfathomable, yet highly discussed, problem of modern science in its various fields. If the issue is considered in the specific context of contemporary music and art - electroacoustic, multimedia, interactive - questions arise: how do the hearing and the mind react to the new synthesized sounds? What are the mechanisms and rules of multi-sensory perception? Are new perceptual skills developing in the face of new aesthetic situations? Does mankind in the age of the new media take another step on the long path of its "sensory evolution"?

New media art often puts the senses to the proof; it is a game played with perception, with its limitations and capabilities. In turn, intensification of experience appears to the audience as liberation, escapism, but also as a search for new ways of knowing.

\section{Keywords}

senses, multimodal perception, immersion, new media art, neuroaesthetics 